\title{
INFLUENCE OF ORGANIC MANURE, ON MICROBIOLOGICAL PROPERTIES OF CALCAREOUS SOIL
}

\author{
Amit Kumar Pandey ${ }^{1}$, Ashutosh Singh ${ }^{1}$, J. Prasad ${ }^{2}$, Umesh Singh $^{1}$ and Santosh Kumar ${ }^{3}$
}

\begin{abstract}
${ }^{1}$ Department of Soil Science \& Agricultural Chemistry, Bihar Agricultural University, Sabour-813 210, Bhagalpur, Bihar, India ${ }^{2}$ Department of Soil Science \&Agricultural Chemistry, Rajendra Agricultural University, Samastipur, Pusa-848 125, Bihar, India

${ }^{3}$ Department of Agronomy, Bihar Agricultural University, Sabour-813 210, Bhagalpur, Bihar, India
\end{abstract}

Received - July 31, 2017; Revision - October 22, 2017; Accepted - December 13, 2017

Available Online - December 27, 2017

DOI: http://dx.doi.org/10.18006/2017.5(6).886.889

KEYWORDS
Microbial properties
Calcareous soil organic manure
Crop residue
Inorganic fertilizer

* Corresponding author

E-mail: amitpandeybau@gmail.com (Amit Kumar Pandey)

Peer review under responsibility of Journal of Experimental Biology and Agricultural Sciences.

Production and Hosting by Horizon Publisher India [HPI] (http://www.horizonpublisherindia.in/).

All rights reserved.

\begin{abstract}
A long-term field experiment was started during rabi 1988-89 in calcareous soil at RAU, Pusa Farm in split plot design with NPK levels in main plots and organic sources in sub-plots. Rice and wheat as $35^{\text {th }}$ and $36^{\text {th }}$ crop were grown for present investigation. Post-harvest soil samples were analysed for bacterial, fungal and actinomycetes population. Result of study revealed a considerable increase in the population of bacteria, fungi and actinomycetes with continuous application of chemical fertilizers and organic manure alone or in combination. Bacterial population increased to a tune of 8.73, 24.60 and 28.82 per cent over control $\left(31.50 \times 10^{6} \mathrm{cfu} \mathrm{g}^{-1}\right.$ soil $)$ at 50, 100 and 150 per cent NPK application respectively. Further, fungal population increased to $26.5,29.0$ and $30.010^{4} \mathrm{cfu} \mathrm{g}^{-1}$ soil over control (24 x $10^{4} \mathrm{cfu} \mathrm{g}^{-1}$ soil) while this improvement was reported by $2.94,9.41$ and 11.17 per cent in actinomycetes population over control $\left(42.50 \times 10^{5} \mathrm{cfu} \mathrm{g}^{-1}\right.$ soil $)$ at 50,100 and 150 per cent NPK. Incorporation of compost and crop residue also increased the population of bacteria, fungi and actinomycetes.
\end{abstract}

All the article published by Journal of Experimental Biology and Agricultural Sciences is licensed under a Creative Commons Attribution-NonCommercial 4.0 International License Based on a work at www.jebas.org.

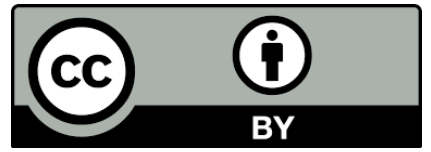




\section{Introduction}

India has the onerous task of feeding almost 17 per cent of the global human population, 11 per cent of the livestock population on only 2-3 per cent of the world's land. There has been a spectacular increase in the use of chemical fertilizers over the past three decades coupled with intensive cropping system as the high yielding cultivars are extremely fertilizer responsive (Jadhao, 2009). Replacement of organic manure by inorganic fertilizers depleted the soil organic matter content. Depletion of organic matter in soil discourages activity of soil micro flora responsible for decomposition of organic matter to enrich soil fertility (Sharma \& Subehila, 2014). Soil organism acts as primary driving agents of nutrient cycling, regulating the dynamics of soil organic matter, soil carbon sequestration greenhouse gas emission, modifying soil structure and water regimes, enhancing the amount of nutrient acquisition by vegetation, conferring stress tolerance, resisting pathogens and improving plant health (Magdoff \& Van Es, 2009). There is meagre information related to the effect of conjoint use of crop residue, compost, and chemical fertilizers on microbial population for soil of Bihar in general and calcareous soil of North Bihar in particular.

\section{Materials and Methods}

A long-term field experiment was started in rabi 1988-89 at RAU Research Farm, Pusa. Rice and wheat crop are being grown continuously under rice-wheat system during Kharif and Rabi season since 1988-89. Rice ( $c v$. Rajshree) and wheat ( $c v$. UP-262) were grown as $35^{\text {th }}$ and $36^{\text {th }}$ test crops, respectively during reported period of 2006-2007. Sixteen treatments comprised of four main plot treatments viz., Control (No NPK fertilizer), 50\% recommended NPK, $100 \%$ recommended NPK \& $150 \%$ recommended NPK along with four sub plot treatments viz., Control (no compost and no crop residue), Compost @ $10 \mathrm{t} \mathrm{ha}^{-1}$, Crop residue \& Compost + crop residue were tested in split plot design with three replications. Different dose of inorganic fertilizers in terms of $\mathrm{N}, \mathrm{P}_{2} \mathrm{O}_{5}$ and $\mathrm{K}_{2} \mathrm{O}$ were applied @ 120: 60: $40 \mathrm{~kg} \mathrm{ha}^{-1}$, respectively as recommended dose in each crop of the rice-wheat sequence. While, nitrogen, phosphorus and potash were supplied in the form of urea $(46 \% \mathrm{~N})$, single super phosphate $\left(\begin{array}{lll}16 \% & \mathrm{P}_{2} \mathrm{O}_{5}\end{array}\right)$ and muriate of potash $\left(60 \% \quad \mathrm{~K}_{2} \mathrm{O}\right)$ respectively. Collected soil samples were stored at low temperature in a deep freezer and used for estimation of different soil biological properties. The population of bacteria, fungi and actinomycetes in

Table1 Influence of organic manure, crop residues and inorganic fertilizers on microbial population after harvest of wheat ( $36^{\text {th }}$ crop) under rice-wheat cropping system in calcareous soil

\begin{tabular}{|c|c|c|c|c|c|c|c|c|c|c|c|c|c|c|c|}
\hline \multirow[b]{2}{*}{ Treatments } & \multicolumn{5}{|c|}{ Bacterial population ( $10^{6} \mathrm{cfu}$ g-1 soil) } & \multicolumn{5}{|c|}{ Fungal population (10 ${ }^{4} \mathrm{cfu}$ g-1 soil) } & \multicolumn{5}{|c|}{ Actinomycetes population ( $10^{5} \mathrm{cfu}$ g-1 soil) } \\
\hline & 之. & 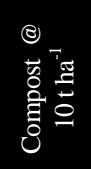 & 它莺 & 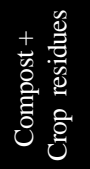 & $\stackrel{\bar{J}}{\mathrm{E}}^{\mathrm{E}}$ & 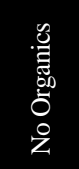 & 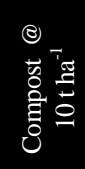 & 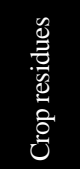 & 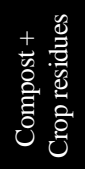 & $\sum_{\Sigma}^{\bar{E}}$ & 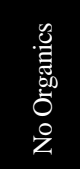 & 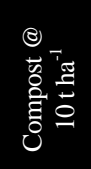 & 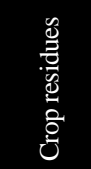 & 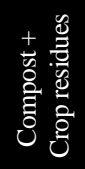 & $\sum_{\bar{E}}^{\bar{E}}$ \\
\hline \multicolumn{16}{|l|}{ Fertilizers } \\
\hline $\begin{array}{c}\text { No } \\
\text { NPK }\end{array}$ & 27.0 & 33.0 & 30.0 & 36.0 & 31.50 & 19.0 & 22.0 & 26.0 & 29.0 & 24.00 & 40.0 & 43.0 & 42.0 & 45.0 & 42.50 \\
\hline $\begin{array}{l}50 \% \\
\text { NPK }\end{array}$ & 30.0 & 36.0 & 32.0 & 39.0 & 34.25 & 21.0 & 25.0 & 28.0 & 32.0 & 26.50 & 41.0 & 45.0 & 43.0 & 46.0 & 43.75 \\
\hline $\begin{array}{l}100 \% \\
\text { NPK }\end{array}$ & 35.0 & 41.0 & 39.0 & 42.0 & 39.25 & 22.0 & 28.0 & 31.0 & 35.0 & 29.00 & 43.0 & 48.0 & 46.0 & 49.0 & 46.50 \\
\hline $\begin{array}{l}150 \% \\
\text { NPK }\end{array}$ & 37.0 & 41.0 & 40.0 & 44.0 & 40.58 & 23.0 & 28.0 & 32.0 & 37.0 & 30.00 & 44.0 & 49.0 & 46.0 & 50.0 & 47.25 \\
\hline Mean & 32.25 & 37.75 & 35.33 & 40.25 & & 21.25 & 25.75 & 29.25 & 33.25 & & 42.00 & 46.25 & 44.25 & 47.50 & \\
\hline & & S.Em. \pm & CD5\% & & & & S. Em. & CD 5\% & & & & S.Em. \pm & CD 5\% & & \\
\hline $\begin{array}{c}\text { Fertilizer } \\
\text { (F) }\end{array}$ & & 0.96 & 3.25 & & & & 1.11 & 3.83 & & & & 0.96 & 3.25 & & \\
\hline $\begin{array}{l}\text { Manure } \\
\text { (M) }\end{array}$ & & 1.08 & 2.97 & & & & 0.977 & 2.85 & & & & 1.08 & 2.97 & & \\
\hline $\mathrm{F} \times \mathrm{M}$ & & 2.00 & NS & & & & 2.02 & 6.23 & & & & 2.00 & NS & & \\
\hline
\end{tabular}

Journal of Experimental Biology and Agriculture Science http://www.jebas.org 
soil was determined by soil dilution and plating technique using Asparagine-Mannitol agar medium (Thornton, 1922); Rose Bengal streptomycin agar medium (Martin, 1950) and Ken Knight and Munaier's medium by pour plate method (Chhonkar et al., 2002), respectively.

\section{Results and Discussion}

Long term effect of graded doses of fertilizers, compost and crop residue either alone or in combination on microbial population has been represented in Table 1.

\subsection{Bacterial Population:}

The data represented in table 1 explained that continuous application of chemical fertilizers, compost and crop residue either alone or in combination significantly increased the population of bacteria in calcareous soil and interaction of these was also found significant. Bacterial population varied from 27.0 to $44.0 \times 10^{6} \mathrm{cfu} \mathrm{g}^{-1}$ soil under different treatment combination. Population of bacteria increased to a tune of 8.73, 24.60 and 28.82 per cent over control $\left(31.5010^{6} \mathrm{cfu} \mathrm{g}^{-1}\right.$ soil) at 50,100 and 150 per cent NPK fertilizer, respectively. This may be due to more proliferation of root exudates and addition of organic matter through stubbles which provide more carbon substrate for microbial growth. Such an increase has also been reported by Kamlesh et al. (1991) and Rajshree \& Piliai (2002). Incorporation of compost, crop residue and compost + crop residue also increased the bacterial population and their effectiveness was in the order of compost + crop residue $\left(40.2510^{6} \mathrm{cfu}^{-1}\right.$ soil $)>$ compost $\left(37.7510^{6} \mathrm{cfu} \mathrm{g}^{-1}\right.$ soil $)>$ crop residue $\left(35.3310^{6} \mathrm{cfu} \mathrm{g}^{-}\right.$ ${ }^{1}$ soil) > no manure $\left(32.2510^{6} \mathrm{cfu} \mathrm{g}^{-1}\right.$ soil). This might be due to gradual mineralization of organic matter, resulting in release of nutrients in optimum level of better proliferation of soil micro flora (Mahajan et al., 2007). Integration of organics and chemical fertilizers resulted in maximum bacterial population than their alone application. Highest bacterial population $\quad\left(44.010^{6} \mathrm{cfu} \mathrm{g}^{-1}\right.$ soil) was recorded in the plot receiving 150 per cent NPK + compost + crop residue. The results of the present investigation are confirmed by the finding of Mahajan et al.(2007) and Nanda et al.(1988).

\subsection{Fungal Population}

Like bacterial population, continuous application of chemical fertilizer, compost and crop residue either alone or in combination significantly increased the fungal population and their interaction effect was also found to be significant. Fungal population varied from 19.0 to $37 \times 10^{4} \mathrm{cfu} \mathrm{g}^{-1}$ soil under different treatment combination. Fungal population increased from 24 to 26.5, 29.0 and $30.0010^{4} \mathrm{cfu} \mathrm{g}^{-1}$ soil with increasing levels of NPK from 50 to 100 and 150 . This may be due to stimulated growth of fungi by nitrogen fertilization (Sharma \& Sharma, 2002). Incorporation of compost, crop residue and compost + crop residue increased the fungal population to a tune of $21.17,37.64$ and 56.47 per cent, respectively, in organic manures are found more effective in causing significant increase in microbial population. This might to be explained in the light of the heterotrophic nutritional behaviour of micro-organism in soil. Most of the soil micro floras are organ trophic in nature. Different levels of NPK in conjunction with compost and crop residues resulted inhighest fungal population. Maximum fungal population ( $37 \times 10^{4} \mathrm{cfu} \mathrm{g}^{-1}$ soil) was recorded in the plot receiving 150 per cent NPK + compost + crop residue. Result of study revealed that that NPK fertilizer helped in the build-up of microbial population. The positive and significant relationship of organic carbon with micro-organism indicates that the increase in fungal population of soil may be due to high organic matter build-up with the regular addition of crop residue (Mahajan et al., 2007). Cellulolytic micro-organism which degraded plant residues in soil, are known to encourage the proliferation of fungal population in soil (SubbaRao, 1977) Similar, observation has also been reported by Selvi et al.,2005.

\subsection{Actinomycetes population}

The data revealed that compost, crop residue and compost + crop residue either alone or in combination with different levels of NPK increased the actinomycetes population. However, their interaction fails to produce any significant effect. Actinomycetes population increased by $2.94,9.41$ and 11.17 per cent over control $\left(42.50 \times 10^{5} \mathrm{cfu} \mathrm{g}^{-1}\right.$ soil) at 50,100 and 150 per cent NPK levels, respectively. Bharadwaj \& Omanwar (1992) also reported an enhancement of microbial population as a whole (application of $\mathrm{N}$ alone enhanced the actinomycetes population).

Addition of compost, crop residue and compost + crop residue also increased the actinomycetes population to a tune of 10.11 , 5.35 and 13.09 per cent over control $\left(42.010^{5} \mathrm{cfu} \mathrm{g}^{-1}\right.$ soil) and their effectiveness followed the order: compost + crop residue > compost > crop residue > no organics. Naidu et al. (1999) also reported that application of manures and vermi-compost harboured significantly more actinomycetes in soil than the control. Actinomycetes population varied from 40.0 to $50.0 \times 10^{5}$ $\mathrm{cfu}^{-1}$ soil under different treatment combination and maximum population of actinomycetes registered when chemical fertilizer integrated with organic manure. The plot receiving 150 per cent NPK and compost + crop residue registered maximum actinomycetes population $\left(50.010^{5} \mathrm{cfu}^{-1}\right.$ soil). The increased actinomycetes population due to application of inorganic fertilizer and organic manure might be due to manifesting the gradual exhaustion of assimilable organic nutrient from compost and crop residue by various soil micro-organism. Selvi et al. (2005) also reported that inorganic fertilizer in combination with organic manure has significant positive effect on actinomycetes 
population. The results of present findings are in agreement with the finding of Mahajan et al. (2007).

\section{Conclusion}

Result of study revealed a considerable increase in the population of bacteria, fungi and actinomycetes with continuous application of chemical fertilizers and organic manure alone or in combination. Further study required which can confirm the facts that either chemical fertilizers did not show any negative impact of the soil microflora or soil microflora mitigate the adverse effect of chemical fertilizers.

\section{Acknowledgement}

The authors are thankful to the Director Research of the Experiment Station, R.A.U. Pusa, Samastipur, Bihar for provide the financial assistance through the Soil Test Crop Response Correlation Scheme to carry out the present investigation.

\section{Conflict of Interest}

Authors would hereby like to declare that there is no conflict of interests that could possibly arise.

\section{References:}

Bharadwaj V, Omanwar PK (1992) Impact of long term fertility treatments on bulk density, water content and microbial population of soil. Journal of the Indian Society of Soil Science 40: 553-555.

Chhonkar PK, Bhadraray S, Patra AK, Purakayastha TJ (2002) Experiments in Soil Biology and Biochemistry. Westville Publishing House, New Delhi .180p.

Jadhao SD (2009) Effect of Long-Term Fertilization on Yield and Soil Chemical Properties under Sorghum (Sorghumbicolor)Wheat (Triticumaestivum) Cropping Sequence. In: Proceedings IPI OUAT IPNI International Symposium, held in 2009 at Bhubaneswar, India.

Kamlesh K, Mishra MM, Dhankar SS, Kapoor KK, Gupta AP (1991) Effect of long term manurial application on microbial biomass. Journal of the Indian Society of Soil Science 39: 685688.

Magdoff F, VenEs H (2009) Building soils for better crops sustainable soil management. Sustainable Agriculture Research and Education ( $3^{\text {rd }}$ Edition) Pp 310.

Mahajan S, Kanwar SS, Kumari P, Sharma SP (2007) Long term effect of mineral fertilizers and amendments on microbial dynamics in an Alfisol of Klestern Himalayas. Indian Journal of Microbiology 47: 86-89.

Martin JP (1950) Use of acid rose Bengal and Streptomycin in the plate method for estimating soil fungi. Soil Science 69: 215.

Naidu AK, Kushwah SS, Dwivedi YC (1999) Performance of organic manure, bio and chemical fertilizers and their combination on microbial population of soil and growth and yield of Okra. Jawaharalal Neharu Krishi VishwaVidhyalaya Research Journal 33: 34-38.

Nanda SK, Das PK, Beherea B (1988) Effect of continuous manuring on microbial population, ammonification and $\mathrm{CO}_{2}$ evolution in a rice soil. Oryza 25: 413-416.

Rajasree G, Piliai GR (2002) Influence of nitrogen nutrition on soil microbial population. Annals of Agricultural Research 23: 331-333.

Selvi D, Santhy P, Dhakshinamoorthy M (2005) Effect of inorganic alone and in combination with farm yard manure on physical properties and productivity of vertic Haplusteps under long-term fertilization. Journal of the Indian Society of Soil Science 53: 302-307.

Sharma M, Sharma SK (2002) Effect of organic amendments on soil microbial population in relation to Dematophora necatrix causing white root of apple. Plant Disease Research 17: 9-15.

Sharma U, Subehila SK (2014) Effect of long term integrated nutrient management on rice (Oryzasativa L.)- Wheat (Triticumaestivum L.) productivity and soil properties in North Western Himalayas. Journal of Indian Society of Soil Science 62: 248-254.

SubbaRao NS (1977) Soil Microbiology.4th Ed., Oxford \& IBH Publishing Co. p94.

Thornton HC (1922) On the development of standardized agar medium for counting of soil bacteria with special regard to repression of spreading colonies. Annals of Applied Biology 9: 241 . 